\title{
Efficiency of Water Use in Sugar Beet and Processing Tomato Cropped in Southern Italy
}

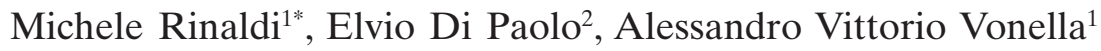 \\ ${ }^{1}$ Istituto Sperimentale Agronomico - C.R.A. \\ Via Celso Ulpiani 5, 70125 Bari, Italy \\ ${ }^{2}$ Centro per la Sperimentazione e Divulgazione delle Tecniche Irrigue \\ S.S. 16 Nord 240, 66054 Vasto (Chieti), Italy
}

Received: 7 June 2005. Accepted: 17 March 2006

\begin{abstract}
A more efficient crop water use in biomass and yield accumulation can represent great water saving in the waterlimited environments. Crop management - irrigation, sowing time, fertilization - could affect water (and irrigation water) transformation efficiency in dry matter and commercial yield of beet and tomato in Southern Italy. This field research, carried out in two locations of Southern Italy (Foggia and Vasto) in 1998-2002 period, compared for sugar beet irrigation regimes (optimal, $100 \%$ of ETc and reduced, $60 \%$ of ETC) and sowing times (autumnal and spring); for tomato three irrigation regimes were compared, re-establishing $100 \%\left(\mathrm{ET}_{100}\right), 66\left(\mathrm{ET}_{66}\right)$ and $33 \%\left(\mathrm{ET}_{33}\right)$ of crop evapotranspiration. Water and irrigation water transformation efficiency in harvestable yield $\left(W U E_{h d m}\right.$ and $I R$ $\left.R W U E_{h d m}\right)$, in total dry matter $\left(W U E_{d m}\right.$ and $\left.I R R W U E_{d m}\right)$ and sucrose $\left(W U E_{s u c}\right)$ were calculated both at harvest and during crop cycle. The results showed a significant effect of sowing date on $W U E_{h d m}$ and $W U E_{s u c}$ of sugar beet (respectively 2.44 and 2.12 for autumnal sowing and 1.08 and $0.84 \mathrm{~kg} \mathrm{~m}^{-3}$ for spring sowing). Irrigation regimes did not show significant differences. "Irrigation $x$ sowing times" interaction was significant for $W U E_{d m}$, with a superiority of reduced vs. optimal only in spring sowing time. In tomato, $W U E_{d m}$ was not affected by the irrigation regime, while $W U E_{h d m}$ in $\mathrm{ET}_{66}$ treatment was more efficient treatment than $\mathrm{ET}_{100}\left(1.19\right.$ vs. $\left.1.00 \mathrm{~kg} \mathrm{~m}^{-3}\right)$. "Year" effect was significant for $W U E_{d m}$ and $W U E_{h d m}$ with lowest values in the driest year. IRRWUE was higher in tomato than in sugar beet, considering dry matter, fresh harvestable product and also from an economic point of view. The temporal analysis of water use efficiency showed $W U E_{d m}$ and $W U E_{h d m}$ greater in the middle of crop cycle in autumnal than in spring sugar beet, but not between the irrigation regimes. In tomato, the $\mathrm{ET}_{66}$ treatment resulted the most efficient in water using, especially at the end of crop cycle. This information can be useful in the crop management of sugar beet and tomato in Southern Italy and to better address the scarce irrigation water resources.
\end{abstract}

Key-words: irrigation level, sowing time, yield, water use efficiency, sucrose.

\section{Introduction}

An efficient capability of crop in water using for biomass and commercial yield production can represent great water saving in water-limited environments. Sugar beet (Beta vulgaris L.) and processing tomato (Lycopersicon esculentum Mill.) are important irrigated crops in Southern Italy; their seasonal water use in Mediterranean environments range from 500 to $900 \mathrm{~mm}$ for sugar beet and from 300 to $600 \mathrm{~mm}$ for tomato (Allen et al., 1998), covered on average by $40 \%$ ( $70 \%$ for spring sowing time) and $75 \%$ by irrigation supplies, respectively for sugar beet and processing tomato.
Water use efficiency (WUE) is related to species, genotype and management practices and it is defined as the ratio of biomass $(Y)$ produced per unit of water resource. Water used to produce biomass is the sum of evaporation from the soil $(E s)$, transpiration of the crop $(T)$, runoff $(R)$, drainage below the root zone $(D)$, so the equation (Gregory et al., 2000) to describe $W U E$ can be written as:

$$
W U E=\frac{\left(\frac{Y}{T}\right)}{\left(1+\frac{(E S+R+D)}{T}\right)}
$$


This equation makes clear that WUE can be improved by increasing crop dry matter production or decreasing the water losses for $E s, R$ and $D$.

Efficiency values for water conversion in dry matter $\left(W U E_{d m}\right)$ of sugar beet are reported to be between 4.6 and $5.6 \mathrm{~kg} \mathrm{~m}^{-3}$ of used water (Brown et al., 1987). Dunham (1993) reviewed $W U E_{d m}$ values ranging from 2.1 to $10.0 \mathrm{~kg} \mathrm{~m}^{-3}$ in several environments; in experimental areas with seasonal water use close to Southern Italy conditions $(600-900 \mathrm{~mm})$, the values ranged from 2.3 to $5.8 \mathrm{~kg} \mathrm{~m}^{-3}$. This suggests that sugar beet, a $\mathrm{C}_{3}$ species, is an efficient user of water, even comparable to maize, a $\mathrm{C}_{4}$ species (Tanner and Sinclair, 1983). Water use efficiency for sucrose production $\left(W U E_{s u c}\right)$, showed a linear increase with water irrigation amount, ranging from 0.7 to $1.6 \mathrm{~kg} \mathrm{~m}^{-3}$ in spring sown beet (Cassel and Bauer, 1976). Davidoff and Hanks (1989) concluded that sugar beet yield was related to root yield and not to sucrose content, and that sucrose content was not affected by irrigation treatments and water levels: reported values of $W U E_{s u c}$ were from 0.8 to $1.7 \mathrm{~kg} \mathrm{~m}^{-3}$. Also Dunham (1993) reported values for $W U E_{s u c}$ from 1.1 to $2.5 \mathrm{~kg} \mathrm{~m}^{-3}$ in the locations with $600-$ $900 \mathrm{~mm}$ of seasonal water use. Ehlig and LeMert (1979) in autumnal sugar beet in USA reported $W U E_{s u c}$ values of $1.4-2.0 \mathrm{~kg} \mathrm{~m}^{-3}$, inversely related to seasonal water use. No evidences were found in literature about WUE of sugar beet when submitted at the same time to sowing times and irrigation regimes.

Raina et al. (1999) compared different irrigation systems on field tomato and obtained water use efficiency values for harvestable dry matter $\left(W U E_{h d m}\right)$ of $3.4 \mathrm{~kg} \mathrm{~m}^{-3}$ with drip irrigation, 4.8 with drip irrigation plus plastic mulch and $1.6 \mathrm{~kg} \mathrm{~m}^{-3}$ with surface irrigation. $W U E_{h d m}$ ranged from 1.0 to 2.0 as regard as the criteria to schedule irrigation, with pan evaporation readings and tensiometer-controlled irrigation systems, respectively (Scholberg, 1996). Ramalan and Nwokeocha (2000) obtained higher values of $W U E_{h d m}$ with straw mulch respect to bare soil in furrow irrigation method (5.5 and $3.8 \mathrm{~kg} \mathrm{~m}^{-3}$, respectively). Similar results were obtained by Shrivastava et al. (1994) who recorded $W U E_{h d m}$ values from 2.7 to $3.3 \mathrm{~kg} \mathrm{~m}^{-3}$, with higher values obtained with drip irrigation, mulching and irrigation amount of $40 \%$ of cu- mulated Pan evaporation. The effect of irrigation frequency on $W U E$ was studied by Oliveira et al. (1996) who observed a significantly lower $W U E_{d m}$ with irrigation at $-10 \mathrm{kPa}$ (more frequent) than more delayed irrigation treatments. Begum et al. (2001) obtained values of WUEhdm from 3.8 to $4.5 \mathrm{~kg} \mathrm{~m}^{-3}$, with higher values in the not-irrigated treatment. Yohannes and Tadesse (1998) also compared drip vs. furrow irrigation method and different emitters: WUE${ }_{h d m}$ ranged from 1.8 to $4.3 \mathrm{~kg} \mathrm{~m}^{-3}$, with best results with drip irrigation and self-compensating emitters. Irrigation $W U E_{h d m}$ was studied by Imtiyaz et al. (2000) who found for tomato average value of $4.5 \mathrm{~kg} \mathrm{~m}^{-3}$, with a range from 6.6 $\mathrm{kg} \mathrm{m}^{-3}$ in the treatment with irrigation at $33 \mathrm{~mm}$ of cumulated Pan evaporation (CPE), to $2.7 \mathrm{~kg}$ $\mathrm{m}^{-3}$ in the more (with irrigation at $11 \mathrm{~mm}$ of $\mathrm{CPE}$ ) and $2.9 \mathrm{~kg} \mathrm{~m}^{-3}$ in the less irrigated treatment (with irrigation at $55 \mathrm{~mm}$ of CPE).

The aim of this research is to examine the variations of water and irrigation water use efficiencies of sugar beet and processing tomato as affected by irrigation regime and sowing time (for sugar beet only), in order to better address crop management.

\section{Materials and methods}

Field experiments in Foggia (41 $27 " \mathrm{~N})$ and Vasto $\left(42^{\circ} 10^{\prime \prime} \mathrm{N}\right)$ were carried out in the 1998 2002 period.

In Foggia the soil is a vertisol of alluvial origin (Typic Chromoxerert, fine, termic, according to the Soil Taxonomy-USDA), silty-clay with the following characteristics: clay $37.1 \%$, silt $38.0 \%$, sand $24.9 \%, \mathrm{pH}$ (water) 8.3 , total nitrogen $0.12 \%$, organic matter, $2.1 \%, \mathrm{NaHCO}_{3}$-extractable $\mathrm{P} 41 \mathrm{ppm}, \mathrm{NH}_{4} \mathrm{O}$ Ac-extractable $\mathrm{K}_{2} \mathrm{O}$, 1598 ppm, bulk density $1.2 \mathrm{~kg} \mathrm{dm}^{-3}$, field capacity water content $0.40 \mathrm{~m}^{3} \mathrm{~m}^{-3}$; permanent wilting point water content $0.20 \mathrm{~m}^{3} \mathrm{~m}^{-3}$, available soil water $202 \mathrm{~mm} \mathrm{~m}^{-1}$. The climate is "accentuated thermo-mediterranean" (Unesco-FAO classification), with minimum temperatures below 0 ${ }^{\circ} \mathrm{C}$ in the winter and minimum temperatures above $40{ }^{\circ} \mathrm{C}$ in the summer. Annual rainfall (mean $550 \mathrm{~mm}$, considering 50-year long term period) is mostly concentrated during the winter months and class "A pan" evaporation exceeds $10 \mathrm{~mm} \mathrm{~d}^{-1}$ in summer (average of maxi- 
mum daily values recorded in July and August).

In Vasto the soil is a vertisol of alluvial origin (Aquic Haploxerert), silty-clay-loam with the following characteristics: clay $40.7 \%$, silt $52.9 \%$, sand $6.4 \%$, pH (water) 8.2 , total nitrogen $0.14 \%$, organic matter $1.6 \%, \mathrm{NaHCO}_{3}$-extractable $\mathrm{P} 32 \mathrm{ppm}, \mathrm{NH}_{4} \mathrm{O}$ Ac-extractable $\mathrm{K}_{2} \mathrm{O}$, $451 \mathrm{ppm}$, bulk density $1.25 \mathrm{~kg} \mathrm{dm}^{-3}$, field capacity water content $0.40 \mathrm{~m}^{3} \mathrm{~m}^{-3}$; permanent wilting point water content $0.22 \mathrm{~m}^{3} \mathrm{~m}^{-3}$, available soil water $180 \mathrm{~mm} \mathrm{~m}^{-1}$. The climate is "attenuate thermomediterranean" (Unesco-FAO classification), with minimum temperatures below 0 ${ }^{\circ} \mathrm{C}$ in the winter and about $34-36{ }^{\circ} \mathrm{C}$, as maximum temperatures, in the summer. Annual rainfall (mean $650 \mathrm{~mm}$, considering 40-year long term period) is mostly concentrated during the autumn and spring months and class "A pan" evaporation fluctuates, during July and August, between 6 and $8 \mathrm{~mm} \mathrm{~d}^{-1}$ in clear sky days.

Sugar beet was sown in autumn (in October) and in spring (in March) and irrigated re-establishing the 100\% (optimal) and at 60\% (reduced) of crop evapotranspiration $(E T c)$; tomato was irrigated re-establishing the 100, 66 and $33 \%$ of ETc $\left(\mathrm{ET}_{100}, \mathrm{ET}_{66}\right.$ and $\left.\mathrm{ET}_{33}\right)$.

Irrigation was scheduled on the basis of a water balance, calculated as the sum of estimated daily ETc, subtracting the fraction of rainfall not exceeding the field capacity (equal to soil moisture deficit, SMD). ETc was calculated as proposed by the FAO, where reference evapotranspiration (ETo) was calculated using the Penman-Monteith model, before being modified by a crop coefficients (Allen et al., 1998).

For sugar beet, when the cumulated $S M D$ reached $60 \mathrm{~mm}$, optimal treatment $(100 \%$ of $E T c$ ) was irrigated with $60 \mathrm{~mm}$ and reduced one ( $60 \%$ of $E T c$ ) with $36 \mathrm{~mm}$, except for the first two irrigations at sowing and emergence, which were the same for both treatments. Irrigation was ended about one month before the presumable harvest date. The irrigation method was drip irrigation, with one line for each plant row (0.5 m apart) and drippers of $4 \mathrm{~L} \mathrm{~h}^{-1}$ flow, 0.3 $\mathrm{m}$ apart.

For tomato, every time the cumulated $S M D$ reached $40 \mathrm{~mm}$ irrigation was applied with 40 $\mathrm{mm}, 26 \mathrm{~mm}$ and $13 \mathrm{~mm}$ respectively for treatment $\mathrm{ET}_{100} \mathrm{ET}_{66}$ and $\mathrm{ET}_{33}$. Treatment $\mathrm{ET}_{33}$ was studied only in 1999 . Tomato irrigation was end- ed at least 10 days before the presumable harvest date deduced on the basis of the percentage of fruit ripened. To ensure uniform water distribution, a drip irrigation system was used, with one emitter line for each combine of plant rows (1.8 $\mathrm{m}$ apart between lines) and drippers of $4 \mathrm{~L} \mathrm{~h}^{-1}$ flow, $0.3 \mathrm{~m}$ apart. A water flow meter was placed at the head of each plot to measure accurately the amount of irrigation water applied.

A randomised block design with three replications was used; the usual crop management for sugar beet was adopted, with a plant population of 100,000 plants ha $^{-1}$ for beet and 32,000 for tomato. Main details of the experiments are reported in table 1 .

Growth analysis was carried out for both crops: plant dry matter, separated into roots (for sugar beet only), stems, green and dead leaves, and fruits (for tomato only), was measured every 2 weeks by taking one square meter sample for sugar beet and six plants for tomato from every plot and dried at $80{ }^{\circ} \mathrm{C}$ until weight was constant.

At harvest, the total plant dry matter was determined after drying at $80{ }^{\circ} \mathrm{C}$. Beet sucrose content (\%) was measured with a polarimeter after extraction of sugar from the pulp with lead acetate. Sucrose yield $\left(\mathrm{t} \mathrm{ha}^{-1}\right)$ was calculated by multiplying fresh root yield and sucrose content.

Seasonal water use $(W U)$ was estimated according to the following water balance equation:

$$
W U= \pm \Delta S W C+R+I-D
$$

where " $\triangle S W C$ " is the variation, between seeding and harvest date, of the volumetric soil water content in the 0-0.6 m depth layer, measured with the gravimetric method, $R$ is the rainfall, $I$ the irrigations and $D$ the water lost for deep percolation, all expressed in $\mathrm{mm}$. The $D$ term was calculated according to a water balance approach, using daily values of ETc, rainfall and irrigation and starting from measured soil water content at sowing with gravimetric method. Whenever field capacity was exceeded, the deep percolation water was calculated subtracting soil water content from field capacity: the soil water content was reset at field capacity. This water balance model considers the losses for surface runoff and capillary return to be negligible. Despite the fact that beet and tomato roots can reach deep layers $(>0.6 \mathrm{~m})$, the presence of a 
Table 1. Brief description of sugar beet and tomato crop management of experimental data set used in this research.

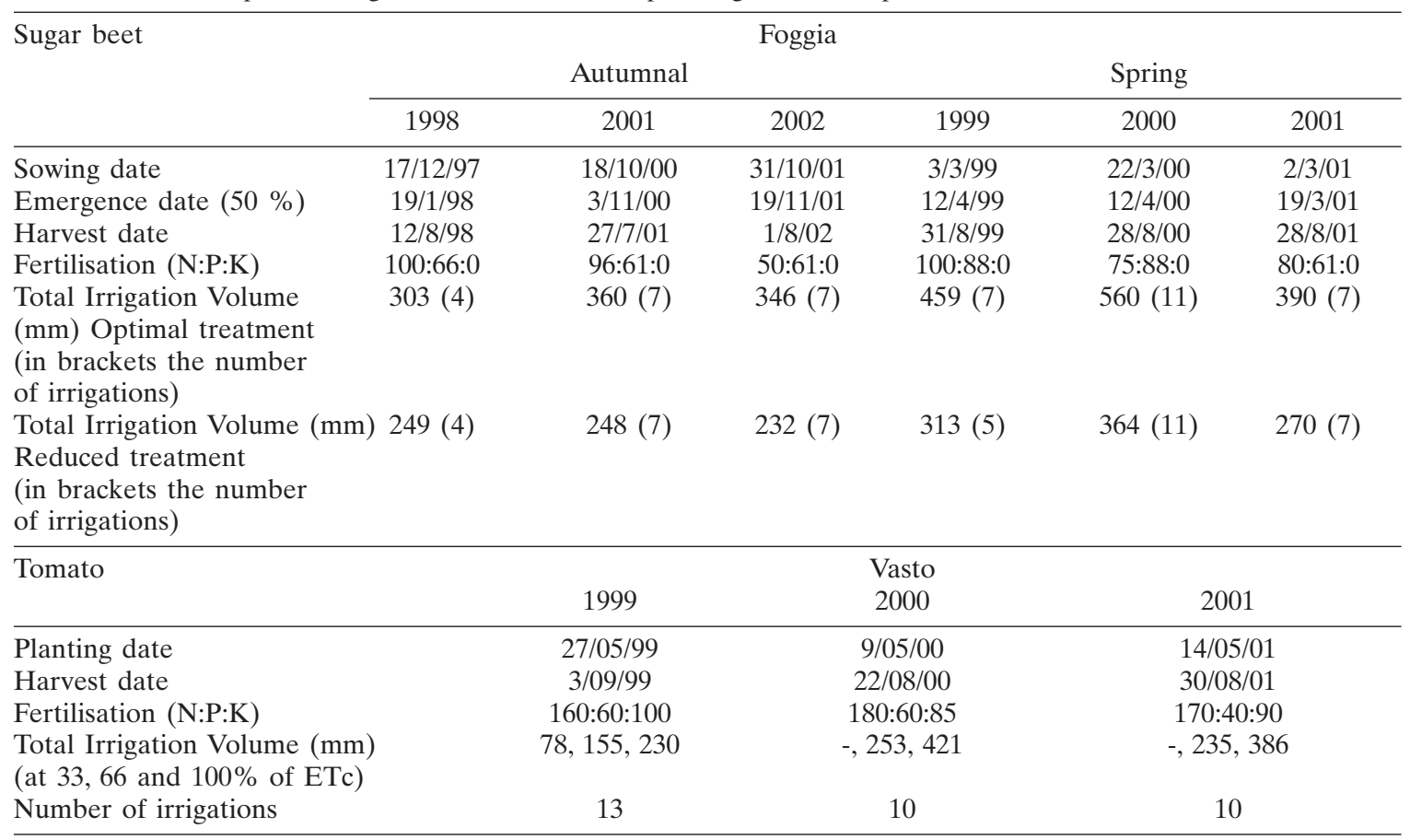

compact calcareous layer reduces the root depth and allowed us to limit at $0.6 \mathrm{~m}$ the depth of soil samples.

$W U$ was calculated using the equation (2) also during the crop cycle, when $S W C$ was measured in the same day of plant sampling.

Water use efficiency for total biomass $\left(W U E_{d m}\right)$ and harvestable $\left(W U E_{h d m}\right)$ - roots for sugar beet and fruits for tomato - dry matter production $\left(\mathrm{kg} \mathrm{m}^{-3}\right)$ was calculated by ratio with $W U\left(\mathrm{~m}^{3}\right)$, both at seasonal and at sampling dates during crop cycle. $W U E_{s u c}$ for sugar beet was calculated at harvest by mean sucrose yield and $W U$ ratio.

In order to calculate water use efficiency of irrigation supply (IRRWUE, $\mathrm{kg} \mathrm{m}^{-3}$ ) a simulation activity was carried out to forecast the yield of both crops in rainfed condition because a "not irrigated" control treatment was not considered in the planning of experiment, for the high risk of crop failure for drought and because this crop management is not usually adopted in the two environments. Epic model (Williams et al., 1989; Sharpley and Williams, 1990), calibrated and validated in both locations (Rinaldi et al., 2000, 2001), was used with daily climatic data, soil and management information to simu- late rainfed treatment. Irrigation water efficiencies in total dry matter $\left(I R R W U E_{d m}\right)$ and harvestable yield (roots for beet; fruits for tomato, $\left.I R R W U E_{h d m}\right)$ were calculated as ratio of increased yield respect to rainfed treatment simulated by the model vs. seasonal irrigation water applied. IRRWUE of fresh harvestable yield of both crops was calculated using an average dry matter content of $5 \%$ for tomato fruits and $25 \%$ for sugar beet roots.

Accumulated average temperatures above a threshold, called base temperature, is commonly used to compare crop phenological period length, especially in the comparison of different sowing times, where the number of days cannot give the correct information about the phenological time duration. Growth Degree Days $(G D D)$ were calculate daily and cumulated from emergence to harvest, using a base temperature of $+3{ }^{\circ} \mathrm{C}$ for sugar beet and $+10{ }^{\circ} \mathrm{C}$ for tomato (Milford et al., 1985). An analysis of water use efficiencies (WUEs) during crop cycle was carried out for both crops, using $G D D$ as regressor and fitting second or third order polynomial equations.

Analysis of variance of WUEs and $I R$ $R W U E s$ at harvest was performed using a ran- 
Table 2. Water Use Efficiency for total dry matter $\left(W U E_{d m}\right)$, harvestable dry matter $\left(W U E_{h d m}\right)$ and sucrose yield $\left(W U E_{s u c}\right)$ all expressed in $\mathrm{kg} \mathrm{m}^{-3}$, of sugar beet submitted to two sowing times (autumnal and spring) and two irrigation regimes (optimal and reduced) in three years of experiment. For $W U E_{d m}$ interaction "Sowing time $x$ Irrigation", for $W U E_{h d m}$ and $W U E$ suc "Sowing times" effects were significant at $\mathrm{P}<0.05$ level. Different letters indicate significant differences between means at $\mathrm{P}<0.05$ level (LSD test).

\begin{tabular}{lcccccccccc}
\hline & \multicolumn{3}{c}{$W U E_{d m}$} & \multicolumn{3}{c}{$W U E_{\text {hdm }}$} & \multicolumn{3}{c}{$W U E_{\text {suc }}$} \\
\cline { 2 - 10 } & Optimal & Reduced & Avg. & Optimal & Reduced & Avg. & Optimal & Reduced & Avg. \\
\hline Autumnal & 2.79 & 2.64 & 2.71 & 2.38 & 2.49 & $2.44 \mathrm{~A}$ & 1.14 & 1.03 & $1.08 \mathrm{~A}$ \\
Spring & 2.79 & 3.09 & 2.94 & 2.15 & 2.09 & $2.12 \mathrm{~B}$ & 0.83 & 0.84 & $0.84 \mathrm{~B}$ \\
Avg. & 2.79 & 2.87 & 2.83 & 2.27 & 2.29 & 2.28 & 0.99 & 0.94 & 0.96 \\
\hline
\end{tabular}

domized block design; for sugar beet, after testing not significant effects of year and its interactions with irrigation treatment and sowing times, the "year" effect was pooled in the residual error. For tomato, the analysis of variance was performed for common irrigation treatments $\left(\mathrm{ET}_{100}\right.$ and $\left.\mathrm{ET}_{66}\right)$ comparing the three years of experiment, considering the "year" effect as random factor; in addition, year 1999, when the $\mathrm{ET}_{33}$ irrigation treatment was also studied, was analysed separately. Least Statistical Difference was used as mean separation test to discriminate the compared treatments.

\section{Results and discussion}

The experimental results indicated how the significant interaction "sowing time $x$ irrigation" showed a parity between the two irrigation schedules in autumnal crop, but a superiority of reduced $\left(3.09 \mathrm{~kg} \mathrm{~m}^{-3}\right)$ vs. optimal $\left(2.79 \mathrm{~kg} \mathrm{~m}^{-3}\right)$ irrigation regime with spring sowing time (Table 2 ). This is explainable by the less importance of irrigation practice during winter-spring than spring-summer growth period. In fact, in spring sowing time, sugar beet crop growth is more dependent by water supply because rainfall during spring and summer cannot satisfy completely crop water requirement.

A significant difference was noticed between the two sowing times for $W U E_{h d m}$ parameter, higher in autumnal than in spring sowing date (Table 2). The period of maximum allocation of biomass in the sink organs (roots) is in MayJune for the autumnal sugar beet, June-July for the spring one: in both case the period is usually warm and drought in Southern Italy and so, the efficiency of water use in root biomass production is higher when the biomass accumula-
Table 3. Water Use Efficiency for total dry matter $\left(W U E_{d m}\right)$ and harvestable dry matter $\left(W U E_{h d m}, \mathrm{~kg} \mathrm{~m}^{-3}\right)$ of processing tomato submitted to two irrigation regimes in the three years of experiment. Different letters indicate significant differences between means at $\mathrm{P}<0.05$ level (LSD test).

\begin{tabular}{lll}
\hline & $W U E_{d m}$ & $W U E_{h d m}$ \\
\hline $\mathrm{ET}_{100}$ & 2.04 & $1.00 \mathrm{~B}$ \\
$\mathrm{ET}_{66}$ & 2.19 & $1.19 \mathrm{~A}$ \\
\hline 1999 & $2.31 \mathrm{~A}$ & $1.25 \mathrm{~A}$ \\
2000 & $1.85 \mathrm{~B}$ & $0.88 \mathrm{~B}$ \\
2001 & $2.25 \mathrm{AB}$ & $1.11 \mathrm{~A}$ \\
\hline
\end{tabular}

tion occurs in a more favourable period, characterised mainly by lower vapour pressure deficit (Rinaldi and Vonella, 2005).

Higher values of $W U E_{\text {suc }}$ were observed in sugar beet sown in autumn (Table 2), in dependence of the more favourable climatic conditions during maximum plant growth (MarchMay for the autumnal, May-July for the spring). The values obtained in this experiment confirmed the values obtained by Davidoff and Hanks (1989) and the poor effect of irrigation levels on $W U E_{\text {suc }}$. Also Dunham (1993) obtained in semi-arid environments comparable values of $W U E_{\text {suc }}$.

Processing tomato was characterised by average values of $W U E_{d m}$ very close to those reported in literature for drip irrigation (Shrivastava, 1994; Raina et al., 1999). From table 3 we can observe not significant different values of $W U E_{d m}$ between $\mathrm{ET}_{66}$ and $\mathrm{ET}_{100}$ treatments in the three years of experiment, while the $W U E_{h d m}$ parameter resulted significantly higher in $\mathrm{ET}_{66}$ than in $\mathrm{ET}_{100}$.

"Year" effect was significant for both WUE parameters, with greater values in 1999, lower in 2000. This is explainable for the different climatic conditions, a rainfall during tomato crop cycle four times higher in 1999 than 2000, and 
Table 4. Main climatic variables recorded in Vasto during tomato crop cycle.

\begin{tabular}{lccc}
\hline & $\begin{array}{c}\text { Avg. } \\
\text { temperature } \\
{ }^{\circ} \mathrm{C}\end{array}$ & Rainfall & $\begin{array}{c}\text { Reference ET } \\
\text { (Penman-Monteith) } \\
\text { mm }\end{array}$ \\
\hline 1999 & 22.1 & 174 & 507 \\
2000 & 22.8 & 39 & 429 \\
2001 & 21.7 & 42 & 435 \\
Long-term & 22.3 & 150 & 440 \\
\hline
\end{tabular}

Table 5. Water Use Efficiency for total dry matter $\left(W U E_{d m}\right)$ and harvestable dry matter $\left(W U E_{h d m}, \mathrm{~kg} \mathrm{~m}^{-3}\right)$ of processing tomato submitted to three irrigation regimes in the 1999. Different letters indicate significant differences between means at $\mathrm{P}<0.05$ level (LSD test).

\begin{tabular}{lcc}
\hline Irrigation treatments & $W U E_{d m}$ & $W U E_{h d m}$ \\
\hline $\mathrm{ET}_{100}$ & 2.26 & $1.05 \mathrm{~B}$ \\
$\mathrm{ET}_{66}$ & 2.36 & $1.44 \mathrm{~A}$ \\
$\mathrm{ET}_{33}$ & 2.56 & $1.13 \mathrm{~B}$ \\
\hline
\end{tabular}

Table 6. Irrigation Water Use Efficiency for total dry matter $\left(I R R W U E_{d m}\right)$ and harvestable dry matter $\left(I R R W U E_{h d m}\right)$ all expressed in $\mathrm{kg} \mathrm{m}^{-3}$, of sugar beet submitted to two sowing times (autumnal and spring) and two irrigation regimes (optimal and reduced) in three years of experiment. For IRRWUE $E_{d m}$ "Irrigation", "Sowing time" and "Sowing time x Irrigation" interaction were significant at $0.05 \mathrm{P}$ level. Different letters indicate significant differences between means at $\mathrm{P}<0.05$ level (LSD test).

\begin{tabular}{lcccccc}
\hline & \multicolumn{3}{c}{$I R R W U E_{d m}$} \\
\cline { 2 - 7 } & Optimal & Reduced & Avg. & Optimal & Reduced & Avg. \\
\hline Autumnal & 1.10 & 0.43 & $0.76 \mathrm{~B}$ & 2.06 & 2.41 & 2.23 \\
Spring & 1.68 & 1.69 & $1.68 \mathrm{~A}$ & 2.14 & 1.97 & 2.06 \\
Avg. & $1.39 \mathrm{~A}$ & $1.06 \mathrm{~B}$ & 1.23 & 2.10 & 2.19 & 2.15 \\
\hline
\end{tabular}

different water requirement levels (Table 4). In 1999 the results showed a linear component for $W U E_{d m}$, decreasing with the increasing of percentage of restitution of ET (also if not significant) and a quadratic response for $W U E_{h d m}$, with the greatest values in the $\mathrm{ET}_{66}$ treatment (Table 5).

The IRRWUE is an important parameter in the evaluation of the agronomic and economic good value of irrigation practice.

In sugar beet, the optimal irrigation regime showed a significant superiority of $I R R W U E_{d m}$ respect to reduced but only in the autumnal sowing time, when the irrigation amount influenced the dry matter yield (Table 6). The reasons of this result are similar to those before discussed for $W U E_{d m}$ parameter, and in addition there is the effect of irrigation supplied in a climatic period (May-June) during which the crop canopy of autumnal beet is more active than during the irrigation period of spring beet (MayJuly).

$I R R W U E_{h d m}$ was not affected by sowing time and irrigation regime, highlighting a greater effect of irrigation application on leaves and stems biomass and a lower one on storage organ (roots) (Table 6).

For tomato, irrigation use efficiency for harvestable dry matter was significantly higher in the $\mathrm{ET}_{66}$ treatment compared to $\mathrm{ET}_{100}$ treat- ment in the three years of experiment (Table 7), while for $I R R W U E_{d m}$ no difference was noticed. In the first year of experiment (1999), for the favourable climatic conditions, the tomato crop was characterised by large amount of leaf and stem biomass of the "rainfed" treatment simulated by Epic model, and consequently the $I R$ $R W U E_{d m}$ was significantly lower than the other two years.

In the experiment carried out in 1999, the irrigation efficiency showed the same results observed for the efficiency of water used by tomato: the $\mathrm{ET}_{66}$ was significantly greater than the other two irrigation treatments, not different between them, only for harvestable dry matter (Table 8).

The efficiency of irrigation water supply for

Table 7. Irrigation Water Use Efficiency for total dry matter $\left(I R R W U E_{d m}\right)$ and harvestable dry matter $\left(I R R W U E_{h d m}\right.$, $\mathrm{kg} \mathrm{m}^{-3}$ ) of processing tomato submitted to two irrigation regimes in three years of experiment. Different letters indicate significant differences between means at $\mathrm{P}<0.05$ level (LSD test).

\begin{tabular}{lcc}
\hline & $I R R W U E_{d m}$ & $I R R W U E_{h d m}$ \\
\hline $\mathrm{ET}_{100}$ & 11.80 & $8.61 \mathrm{~B}$ \\
$\mathrm{ET}_{66}$ & 11.51 & $13.07 \mathrm{~A}$ \\
\hline 1999 & $5.29 \mathrm{C}$ & 10.86 \\
2000 & $19.11 \mathrm{~A}$ & 9.91 \\
2001 & $10.57 \mathrm{~B}$ & 11.75 \\
\hline
\end{tabular}


Table 8. Irrigation Water Use Efficiency for total dry matter $\left(I R R W U E_{d m}\right)$ and harvestable dry matter $\left(I R R W U E_{h d m}\right.$, $\mathrm{kg} \mathrm{m}^{-3}$ ) of processing tomato submitted to three irrigation regimes in 1999. Different letters indicate significant differences between means at $\mathrm{P}<0.05$ level (LSD test).

\begin{tabular}{lcc}
\hline Irrigation treatments & $I R R W U E_{d m}$ & $I R R W U E_{h d m}$ \\
\hline $\mathrm{ET}_{100}$ & 6.13 & $6.70 \mathrm{~B}$ \\
$\mathrm{ET}_{66}$ & 4.45 & $15.03 \mathrm{~A}$ \\
$\mathrm{ET}_{33}$ & 3.72 & $8.72 \mathrm{~B}$ \\
\hline
\end{tabular}

the harvestable dry matter was different in the two crops. Comparing only the first two irrigation treatments (average of $\mathrm{ET}_{100}$ and $\mathrm{ET}_{66}$ treatments for tomato and average of optimal and reduced for sugar beet) we obtained 1.23 $\mathrm{kg} \mathrm{m} \mathrm{m}^{-3}\left(I R R W U E_{d m}\right)$ and $2.15 \mathrm{~kg} \mathrm{~m}^{-3}$ (IR$R W U E_{h d m}$ ) for sugar beet (Table 6) and 11.66 $\mathrm{kg} \mathrm{m}^{-3}\left(I R R W U E_{d m}\right)$ and $10.84 \mathrm{~kg} \mathrm{~m}^{-3}$ (IR$R W U E_{h d m}$ ) for tomato, as showed in table 7. It is evident a large superiority (about 5 times) of processing tomato respect to sugar beet in irrigation water use efficiency, that becomes small-
Table 9. Irrigation Water Use Efficiency for fresh harvestable yield (roots for sugar beet and fruits for tomato) $\left(\mathrm{kg} \mathrm{m}^{-3}\right)$.

\begin{tabular}{lccc}
\hline & Tomato & $\begin{array}{c}\text { Autumnal } \\
\text { Sugar } \\
\text { beet }\end{array}$ & $\begin{array}{c}\text { Spring } \\
\text { Sugar } \\
\text { beet }\end{array}$ \\
\hline $\mathrm{ET}_{100}$ (optimal for beet) & 17.2 & 8.25 & 8.57 \\
$\mathrm{ET}_{66}$ (reduced for beet) & 26.1 & 8.56 & 7.90 \\
$\mathrm{ET}_{33}$ (only 1 year) & 17.4 & - & - \\
\hline
\end{tabular}

er if, in this comparison between the two crops, we consider the different dry matter content of harvestable yield (roots and fruits): about 25\% in sugar beet, about $5 \%$ in tomato. Consequently, if we refer this evaluation to fresh harvestable yield we obtained results reported in table 9, confirming, however, a better effectiveness of tomato than sugar beet to use irrigation water. The effectiveness of irrigation depends also by the economic value of fresh harvestable yield in Southern Italy, that is 0,03 for sugar beet and $0,06 € \mathrm{~kg}^{-1}$ for tomato (in the 2006 period):
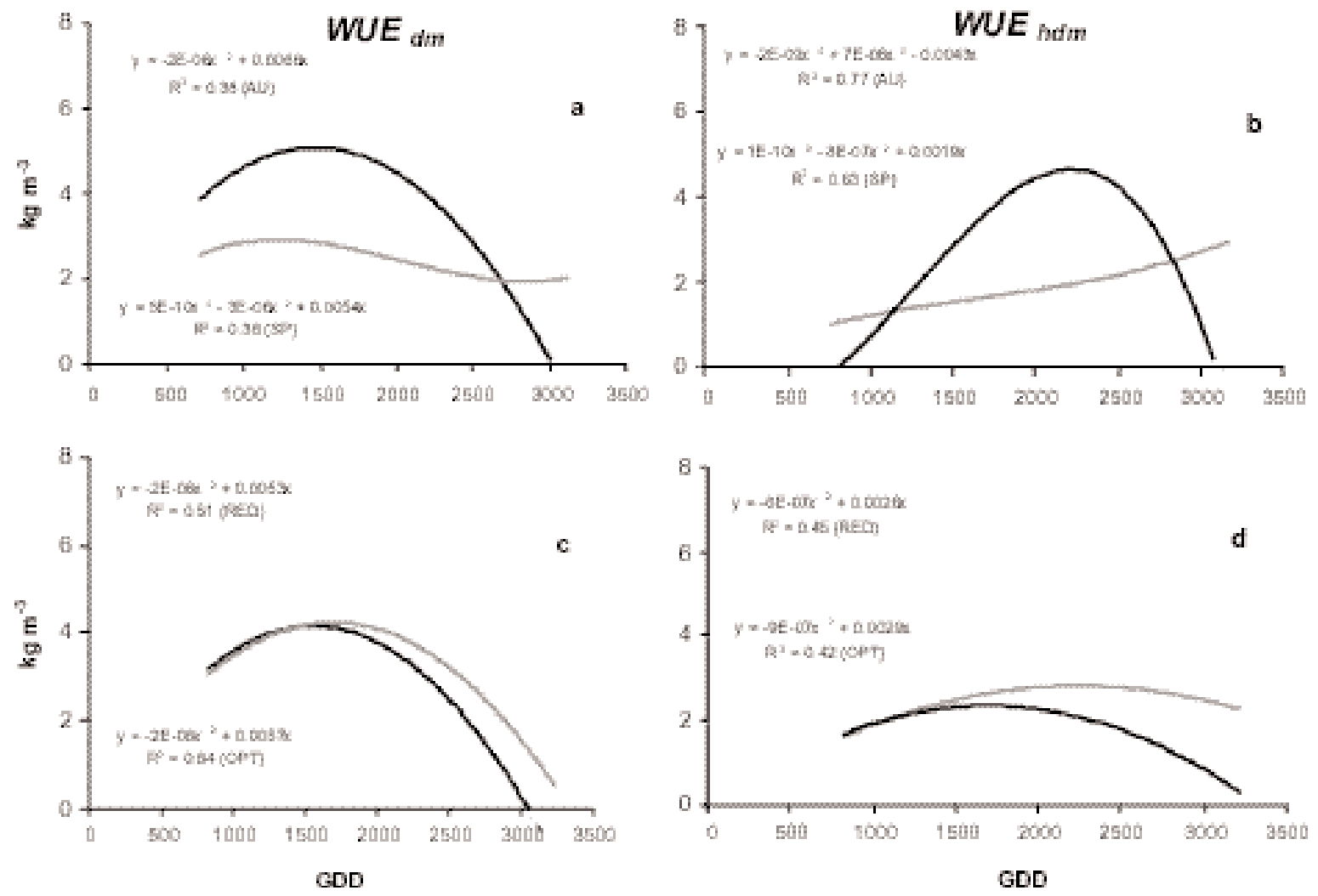

Figure 1. Polynomial lines and equations fitting the 3-year average data of $W U E_{d m}$ and $W U E_{h d m}$ calculated at 14-day interval in sugar beet. Black lines represent autumnal (AU) sowing time in "a" and "b" graphs, optimal (OPT) irrigation regime in "c" and "d"; grey lines represent spring (SP) sowing time (a, b) and reduced (RED) irrigation regime (c, d). 
this corroborates the economical convenience in Southern Italy to use irrigation water for tomato crop rather than for sugar beet.

The temporal analysis of WUEs through the crop cycle (Figures 1a and 1b) pointed up higher values of autumnal than spring sugar beet, especially in the middle of crop cycle (from 1200 to $2800 G D D$ ). In the case of autumnal sowing time, the period of 2000 GDD matches, on average, at April month, while for spring sowing time the period of 1500 GDD is reached in June. The different climatic conditions and water demand during these periods explain also the different maximum values of WUEs recorded by sugar beet autumnal and spring sown. Besides, the figures showed different behaviour in the $W U E_{d m}$ and $W U E_{h d m}$ with maximum values in autumnal reached earlier for $W U E_{d m}$ than for $W U E_{h d m}$, while the function interpolating the data of $W U E_{h d m}$ of spring sugar beet increased over time, indicating a possibility to improve it with crop cycle duration.

In the figures comparing the irrigation regimes (Figures 1c and 1d) the curves interpolating the data of $W U E_{d m}$ and $W U E_{h d m}$ did not differ between the two treatments, except in the latter part of the cycle, when crop evapotranspiration became greater and the difference in soil moisture become more crucial for crop physiological activity.

The tomato crop cycle was shorter (1250 $G D D, 90-110$ days) than sugar beet (3400 vs. $3050 G D D, 240$ vs. 150 days, respectively in autumnal and spring beet) and this also influenced the behaviours of seasonal curves of WUEs, reaching maximum values earlier than sugar beet (Figures 1 and 2).

The temporal analysis of $W U E_{d m}$ of irrigation treatments of tomato (Figure 2) showed constant higher values of $\mathrm{ET}_{66}$ in comparison to more $\left(\mathrm{ET}_{100}\right)$ and less $\left(\mathrm{ET}_{33}\right)$ irrigated treatments, with maximum values around 900 GDD. On the contrary, $W U E_{h d m}$ showed very slight differences among treatments only in the second part of crop cycle (in the 900-1100 GDD period), during fruit ripening and maturation; also for $W U E_{h d m}$ the $\mathrm{ET}_{66}$ treatment showed higher values than the other two irrigation treatments.

\section{Conclusions}

The results of this analysis of water use efficiency of two irrigated field crops in Southern Italy showed an important effect of sowing time in sugar beet, increasing $W U E_{h d m}$ and $W U E_{\text {suc }}$ in autumnal sowing. The irrigation regime influenced water use efficiency for total dry matter only in the autumnal sowing time. The seasonal pattern of $W U E_{d m}$ and $W U E_{h d m}$ showed the superiority of autumnal in the middle of the cycle.

In tomato, the level of water application did not increase $W U E_{d m}$, but $W U E_{h d m}$ was higher in $\mathrm{ET}_{66}$ than $\mathrm{ET}_{100}$ in the 3-year period and, in the first year of experiment, it was also higher than $\mathrm{ET}_{33}$.

The efficiency of using irrigation water was higher in tomato than in sugar beet, also from an economic point of view.
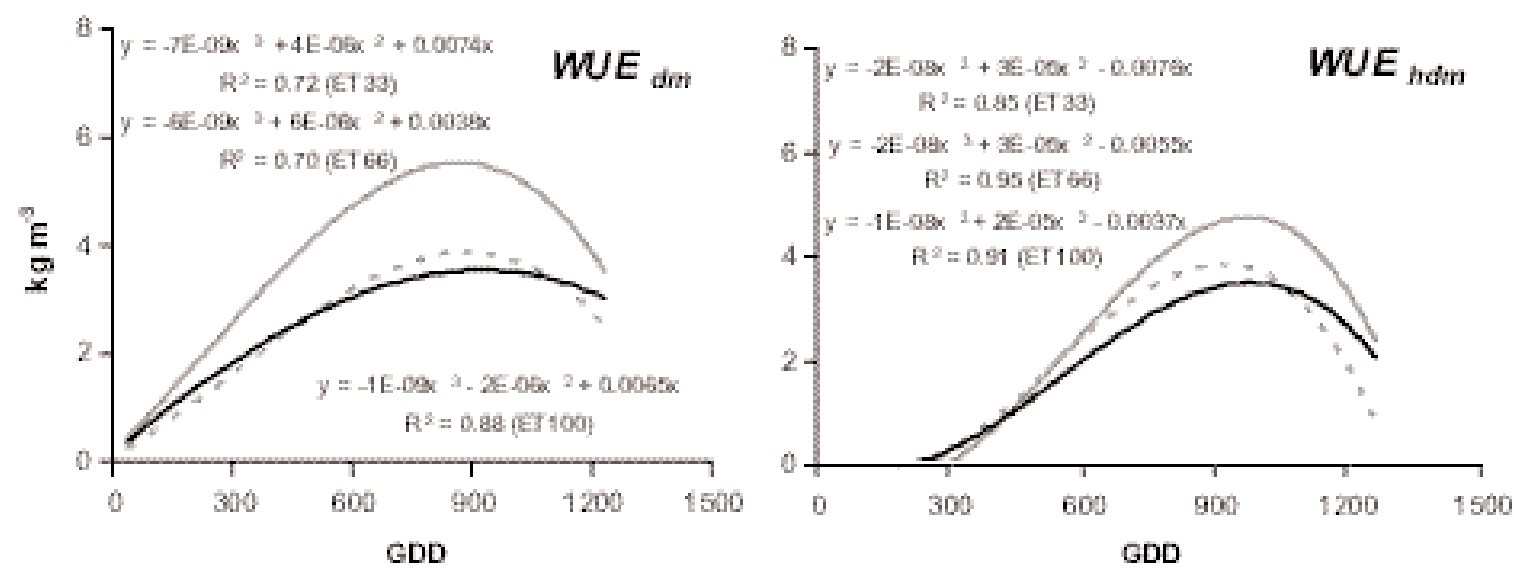

Figure 2. Polynomial lines and equations fitting the average data of $W U E_{d m}$ and $W U E_{h d m}$ calculated at 7-day interval in processing tomato. Black lines represent " $\mathrm{ET}_{100}$ " irrigation regime; grey continue lines " $\mathrm{ET}_{66}$ " and grey dashed line "ET 33 " irrigation regime. 
From this research we can derive useful suggestion for crop management in Southern Italy: for tomato we can propose an irrigation regime with a restoration of $66 \%$ of ETc for sugar beet the autumnal sowing time and the reduced irrigation regime could represent the optimal strategy to use irrigation water in the more effective manner.

\section{References}

Allen R.G., Pereira S., Raes M., Smith M. 1998. Crop evapotranspiration. Guidelines for computing water requirements. FAO-ONU, Rome, Irrigation and Drainage Paper n. 56, 300 pp.

Begum M.N., Karim AJMS, Rahaman M.A., Egashira K. 2001. Effects of irrigation and application of phosphorus fertilizer on the yield and water use of tomato grown on a clay terrace soil of Bangladesh. J. Faculty of Agriculture, 45, 2:611-619.

Brown K.F., Messem A.B., Dunham R.J., Biscoe P.V. 1987. Effect of drought on growth and water use of sugar beet. J. of Agricultural Science, 109:421-435.

Cassel D.K., Bauer A. 1976. Irrigation schedules for sugar beets on medium and coarse textured soils in the Northern Great Plains. Agron. J., 68:45-48.

Davidoff B., Hanks R.J. 1989. Sugar beet production as influenced by limited irrigation. Irrigation Science, 10:1-17.

Dunham R.J. 1993. Water use and irrigation. In: Cooke D.A. and Scott R.K. (eds.): The Sugar Beet Crop: Science into practice, 279-309. Chapman \& Hall.

Ehlig C.F., LeMert R.D. 1979. Water use and yields of sugar beet over a range from excessive to limited irrigation. Soil Science Society Am. J., 43:403-407.

Gregory P.J., Simmonds L.P., Pilbeam C.J. 2000. Soil type, climatic regime, and the response of water use efficiency to crop management. Agron. J., 92:814-820.

Imtiyaz M., Mgadla N.P., Chepete B., Manase S.K. 2000. Response of six vegetables crops to irrigation schedules. Agric.Water Manag., 45:331-342.

Milford G.F.J., Pocock T.O., Riley J. 1985. An analysis of leaf growth in sugar beet. I. Leaf appearance and expansion in relation to temperature under controlled conditions. Ann. of Applied Biology, 106:163-172.

Oliveira M.D.G., Calado A.M., Portas C.A.M. 1996.
Tomato root distribution under drip irrigation. J. of the Am. Soc. for Horticultural Science, 121, 4:644-648.

Raina J.N., Thakur B.C., Verma M.L. 1999. Effect of drip irrigation and polyethylene mulch on yield, quality and water-use efficiency of tomato (Lycopersicon esculentum). Indian J. of Agricultural Sciences, 69, 6:430-433.

Ramalan A.A., Nwokeocha C.U. 2000. Effects of irrigation methods, mulching and soil water suction on the growth, yield and water use efficiency of tomato in the Nigerian Savanna. Agric. Water Manag., 45:317330.

Rinaldi M., Di Paolo E., De Gennaro F., Di Lena B. 2000. Il modello EPIC nella simulazione della coltura del pomodoro da industria: primi risultati. Riv. di Irr. e Dren., 47, 3:26-32.

Rinaldi M., Di Paolo E., Colucci R., Di Lena B. 2001. Validation of EPIC model in simulating tomato field crop in Italian environments. Proc. of $2^{\text {nd }}$ International Symposium "Modelling Cropping Systems", Florence (Italy), 16-18 July, 167-168.

Rinaldi M., Vonella A.V. 2005. The response of autumn and spring sown sugar beet (Beta vulgaris L.) to irrigation in Southern Italy: water and radiation use efficiency. Field Crops Res., 95, 2-3:103-114.

Sharpley A.N., Williams J.R. 1990. EPIC-Erosion/productivity impact calculator: 1) Model documentation. US Department of Agriculture Technical Bulletin n. 1768, 235 p. 2) User Manual. U.S. Department of Agriculture Technical Bulletin n. 1768, 127 pp.

Scholberg J. 1996. Adaptive use of crop growth model to simulate the growth of field-grown tomato. $\mathrm{Ph}$ Thesis, University of Florida (FL, USA), Chapter 4: 62-91.

Shrivastava P.K., Parikh M.M., Sawani N.G., Raman S. 1994. Effect of drip irrigation and mulching on tomato yield. Agric. Water Manag., 25:179-184.

Tanner C.B., Sinclair T.R. 1983. Efficient water use in crop production: Research or re-search? In H.M. Taylor, W.R. Jordan, T.R. Sinclair (eds.): Limitations to Efficient Water Use in Crop Production, 1-27.

Yohannes F., Tadesse T. 1998. Effect of drip and furrow irrigation and planting spacing on yield of tomato at Dire Dawa, Ethiopia. Agric. Water Manag., 35:201207.

Williams J.R., Jones C.A., Kiniry J.R. Spanel D.A. 1989. The EPIC crop growth model. Trans. ASAE, 32: 497-511. 